研究

\title{
高感度感温磁性薄膜デバイスの作製と特性評価
}

\author{
安宾 善史, 谷地 善光, 千葉 茂樹, 長田 洋, 関 享士郎 \\ 岩手大学工学部, $\bar{T}$ 020-8551 盛岡市上田 4-3-5.
}

\section{Preparation and Characterization of High Sensitive Temperature-sensitive Magnetic Thin Film Device}

\author{
Yoshifumi Ajishi, Yoshimitsu Yachi, Shigeki Chiba, Hiroshi Osada and Kyoshiro Seki \\ Faculty of Engineering, Iwate Univ., 4-3-5 Ueda, Morioka 020-8551.
}

Received February 9, 1998

\section{SYNOPSIS}

Up to now, the both of bulk and thick film as a temperature-sensitive substance have been provided. However, the sensitivity of these substances with a large heat capacity are low level for minute temperature detection. The development of a thin film following the tendency of a miniaturization and lightweight of an electronic system has been required. Present authors investigated a method of fabricating temperature-sensitive magnetic thin-film device (TMT) via an annealing treatment after the sputtering of a temperature-sensitive ferrite with low Curie temperature as a target. The method has two step profile: after depositing metal components of a temperature-sensitive ferrite on the substrate by sputtering, a high temperature annealing treatment is performed pouring argon gas, as result a ferrite thin film (thickness: $1.5 \mu \mathrm{m}$ ) with spinel structure can be prepared. TMT reproduced faithfully a component of a temperature-sensitive ferrite has the remarkable temperature dependence and a small heat capacity, so responds sharply to a minute temperature variation. Therefore, TMT is expected to be applied to a pyro-magnetic sensor, a biosensor as well as an enzyme sensor.

\section{KEY WORDS}

temperature-sensitive magnetic core, thick film, magnetic thin-film, sputtering, annealing, spinel structure

\section{1 はじめに}

磁性薄膜は，磁気記録やメディアの分野で活用されている が，その磁性は温度依存性が小さく，かつ，高キュリー温度を 有することが重要な条件である，一方，大きな温度依存性を有 する磁性体は, 温度一磁気トランスジューサとして, 計測や制 御の分野で広く利用されており，サーミスタ"にに敵する多機 能性を有している.感温磁性体は室温付近にキュリー温度を有 するフェライトであり, 飽和磁化, 保磁力およびヒステリシス 損失などの磁気特性は顕著な温度依存性を有する.また，セラ ミックスであるため, 優れた耐環境特性を示し, 各種温度セン サとして使用されている”。

現在利用されている感温磁性体はほとんどがバルク型のデバ イスである. 近年, 電子機器の小型化の䞶勢に伴い, 素子の小 型・集積化が進められている。これまで, 感温磁性体の小型化 に関する研究は,印刷法を用いて厚膜化した感温磁性厚膜の作 製例がある ${ }^{2.31}$. また，スパッ夕薄膜を酸素雲囲気中で熱処理す
ればフェライト薄膜が得られるが, 磁化はバルクの $1 / 5$ 程度で あることを以前に報告した ${ }^{4)}$ ここれらの素子は磁化が小さいた め，七ンサに応用する場合，磁気信号変換装置が大型になり， 小型・軽量化が困難である，感温磁性フェライト薄膜 (Temperature-sensitive Magnetic Ferrite Thin-film: TMT と以下略 す)はバルク感温フェライトをターゲットとしてスパッタ後， アルゴン雾囲気中でアニーリング処理を施して成膜される.こ のため,バルク感温フェライトの組成が保持され,バルク感温 フェライトに匹敵する飽和磁化と顕著な温度依存性を併せもっ た磁性薄膜が得られる クロ磁気デバイスとして, 焦性磁気光センサ, 光パターンセン サ,酵素センサなど感温半導体薄膜が使用されている分野への 応用が期待できる。

本研究は, 熱好理パラメータによるTMTの磁気特性の効果 について検討を行ったものである。 


\section{TMTの作製法}

TMTはスパッタリングとアニーリングの工程を経て作製さ れる. Fig.1にTMTの作製工程を示す，主原料である MnO, $\mathrm{ZnO}, \mathrm{Fe}_{2} \mathrm{O}_{3}$ などの金属酸化物および微量添加物を混合し, 800 〜900足で仮焼成する．これをボールミルなどを用いて数 $\mu \mathrm{m}$ まで粉砕した後, バインダ加え加圧成形後, $1200 \sim 1400^{\circ} \mathrm{C}$ で約 4 時間本焼成をおこない, 直径 $8 \mathrm{~cm}$, 厚さ $8 \mathrm{~mm}$ の感温磁 性コア (Temperature-sensitive Magnetic Core: TMC と以下略す) を作製する. 次にTMCをターゲットとしたスパッタリングに より $\mathrm{Si}$ 基板上に金属成分を堆積させる。スパッ夕はAr雲囲気 中で，4時間， RFパワーは $200 \mathrm{~W}, \mathrm{Ar}$ ガス圧 $60 \mathrm{mT}$ orr の条件 下で行った。作製されたスパッ夕薄膜 (Sputtered Thin Film: STF と以下略す)はスピネル構造をとらず非晶質である.したがっ
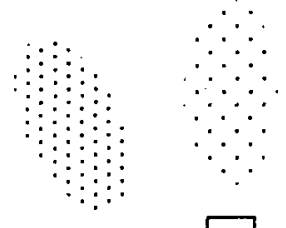

Mixture

of materials

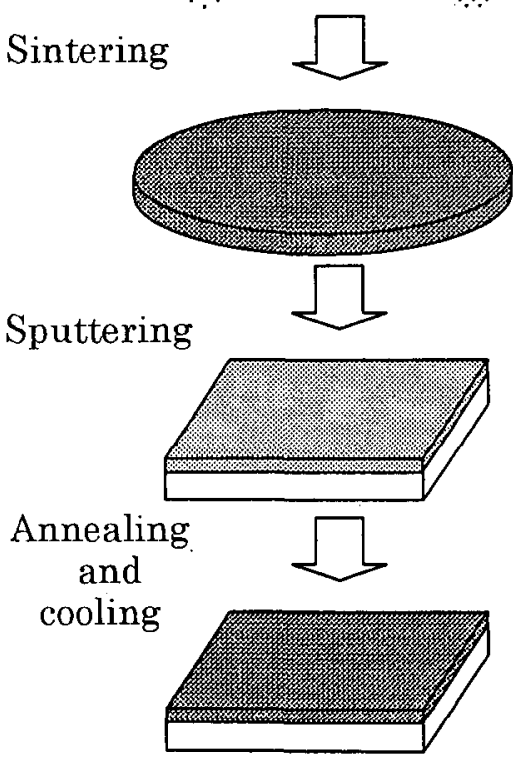

TMC

STF

Fig.1 Flow process for the preparation of the TMT.

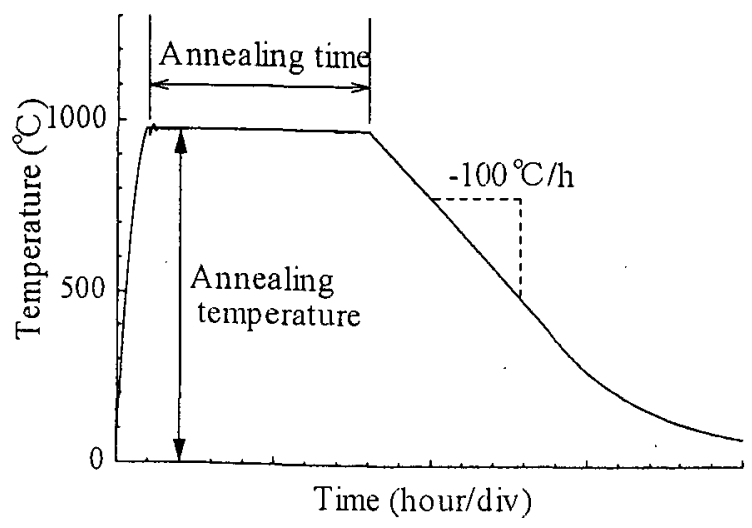

Fig.2 Annealing process for TMT.

TMT
て，磁性はほとんど生じない，そこで，スピネル構造を有す る結晶体に成長させるため, 熱処理工程(Fig.2)が必要となる. スパッ夕膜は，TMCの金属成分を忠実に再現するので，適切 に熱処理された磁性薄膜はTMCと同一キュリー温度を有する 感温膜として成膜されることが予想される。アニーリングは $\mathrm{Ar}$ 堂囲気中にて $900 \sim 1000^{\circ} \mathrm{C} て ゙ 0 \sim 10$ 時間行った。このとき

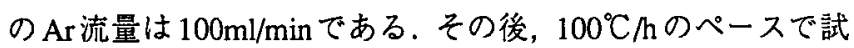
料を室温まで冷却し，TMT (膜厚 $1.5 \mu \mathrm{m}$ ) が作製される。

\section{TMT の基礎特性}

Fig.3にターゲットである TMC, STF, TMT の金属成分比を 示す. TMTは $970^{\circ} \mathrm{C} て ゙ 8$ 時間熱処理を施した試料である. 測 定はX線マイクロアナライザEDXを用いて行った。同表より $\mathrm{TMC}$ の主成分である $\mathrm{Fe}, \mathrm{Mn}, \mathrm{Zn}$ の成分比はそれぞれ $67.07 \mathrm{~mol} \%, 14.73 \mathrm{~mol} \%, 18.20 \mathrm{~mol} \%$ である.STFの成分比は $66.95 \mathrm{~mol} \%, 14.63 \mathrm{~mol} \%, 18.42 \mathrm{~mol} \%$ であり，スパッ夕時におけ る組成ずれはほとんどないことがわかる，また，TMTの成分 比は $67.55 \mathrm{~mol} \%, 14.75 \mathrm{~mol} \%, 17.70 \mathrm{~mol} \%$ であり，アニーリング によるTMT の組成ずれもほとんど見られない。

Fig.4にSTFと TMTのXRDパターンを示す.TMTの熱処理

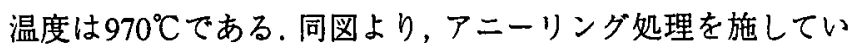
ないSTFはピークが現れず非晶質を示すが，アニーリングに より (220), (311), (400), (440) 面でピーク值が見られ，TMTは スピネル構造を有することがわかる。.また，アニーリング時 間が長くなるにしたがいピーク強度は強まり，8時間のアニー リングでもっとも強くピークが現れる。これよりSTFは適度

\subsection{0}

14.73

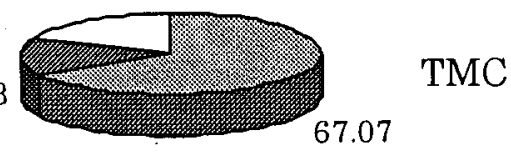

18.42

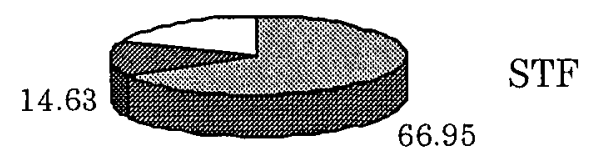

17.70

14.75

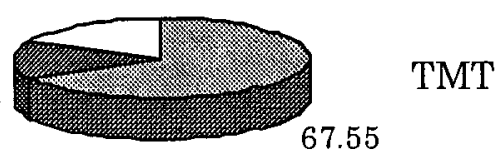

$\mathrm{Fe} \mathrm{Mn} \square \mathrm{Zn}$

(mol\%)

Fig.3 Metal components of various temperature-sensitive magnetic substances. 


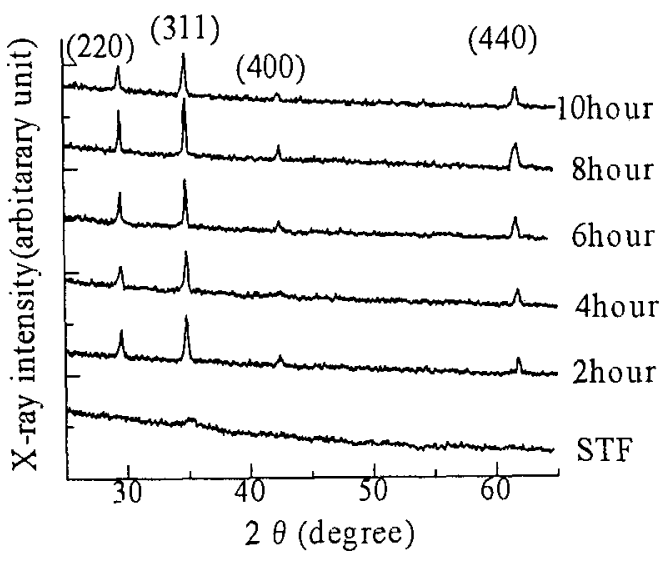

Fig.4 XRD patterns of STF and TMT.

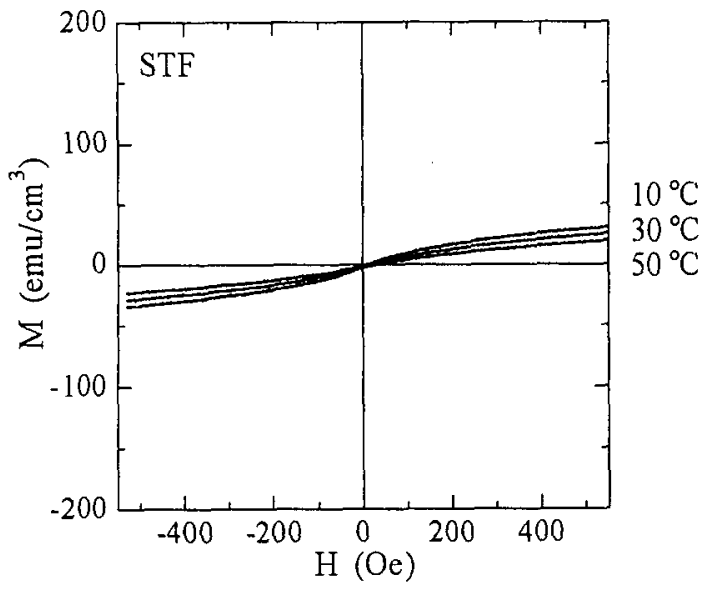

Fig.5 Magnetization curve of STF with temperature change.

の量の $\mathrm{O}_{2}$ を内部に含んでおり，Ar雲囲気でのアニーリングに よってスピネル構造の形成が進むものと思われる。

Fig.5にSTFの磁化特性を示す. 同図より試料温度 $10^{\circ} \mathrm{C}$ と きの飽和磁化 $\mathrm{M}_{\mathrm{s}}$ は $29 \mathrm{emu} / \mathrm{cm}^{3}$ であり，非常に小さいことがわ かる。 また，試料温度が $50^{\circ} \mathrm{C}$ ま卡昇すると飽和磁化は $18 \mathrm{emu} / \mathrm{cm}^{3}$ まで減少する。

Fig.6にTMC, TMT及びスクリーン印刷にて作製した感温磁 性厚膜 (Temperature-sensitive Magnetic Ferrite Thick-film: TTF $と$ 以下略す)の磁化ループを示す. TMTは $970^{\circ} \mathrm{C} て ゙ 8$ 時間アニー リングを施した試料である。同図より TMTの磁化は厚膜TTF のそれを大きく凌ぎ、ほほバルクのTMCに匹敵する磁化を有 することがわかる、また，TMTの保磁力は150eを示し，TMC と比較すると，10数倍の大きさであるが，TMTの形状は薄膜 であるため,バルクや厚膜よりも透磁率が高いことがわかる．

Fig.7にアニーリング温度によるTMTの飽和磁化 $\mathrm{M}_{\mathrm{s}}$ の変化 を示す.アニーリング時間は 8 時間，試料温度は100である。

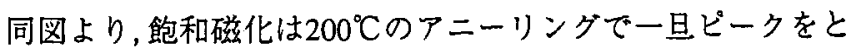
り $47 \mathrm{emu} / \mathrm{cm}^{3}$ を示すが，その後急激に隇少し， $400 \sim 800^{\circ} \mathrm{C} の$ アニーリングでは著しく小さな值をとる.しかしながら, 900

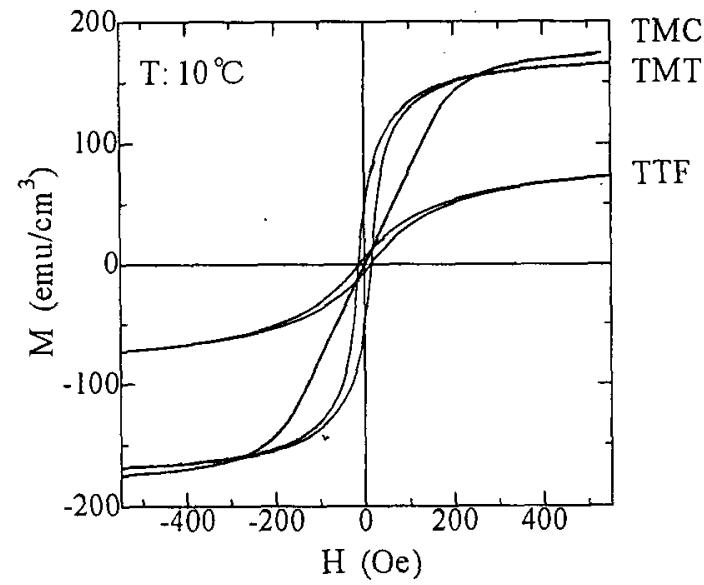

Fig.6 Magnetization loops of various temperature-sensitive magnetic substances.

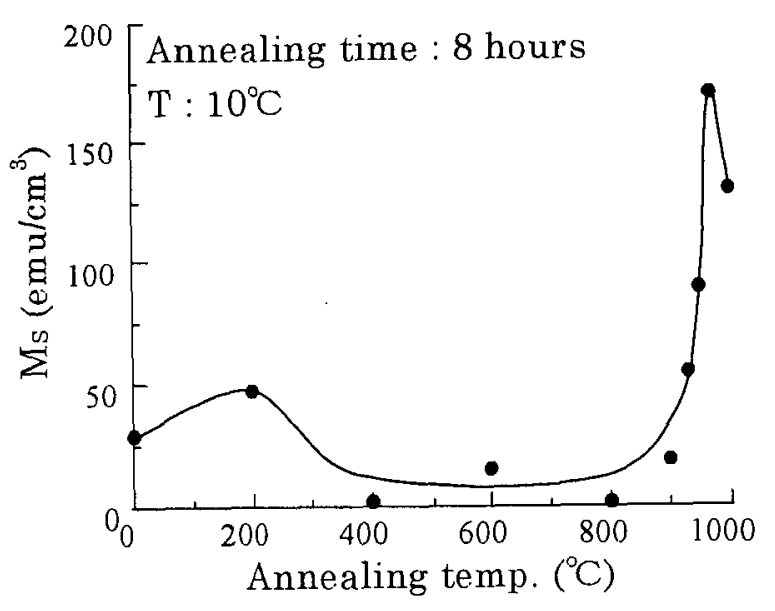

Fig.7 Saturation magnetization $M_{S}$ vs. annealing temperature.

○C以上でのアニーリングにより飽和磁化は急激な增加を示し， $970^{\circ} \mathrm{C}$ で最大值 $165 \mathrm{emu} / \mathrm{cm}^{3}$ をる， $1000^{\circ} \mathrm{C}$ のアニーリングで 飽和磁化は再び減少し $130 \mathrm{emu} / \mathrm{cm}^{3}$ を示す.このような飽和磁 化の振る舞いはTMTの構造に起因するものと思われる，ス パッタリング直後のSTFはアモルファス状態であるが, $200^{\circ} \mathrm{C}$ でのアニーリングにより $\gamma-\mathrm{Fe}_{2} \mathrm{O}_{3}$ 相が形成され磁化が増加す る.しかしそれ以上のアニーリング温度では非磁性の $\alpha-\mathrm{Fe}_{2} \mathrm{O}_{3}$ 相の形成が促進されるため，400 800 Cでアニーリングした TMTはほとんど磁化を示さない.さらにアニーリング温度が 上升した場合，TMTの構造はスピネル相が支配的になるた め, 急激な磁化の增加がみられるものと考えられる”。

Fig.8にTMTの表面写真を示す。(a)は $970^{\circ} \mathrm{C}$ ，(b) は $1000^{\circ} \mathrm{C}$ で8時間アニーリングを施したTMTである，同図より，(a)の 膜の表面は非常に平滑であるが，(b)の膜では表面に凹凸がみ

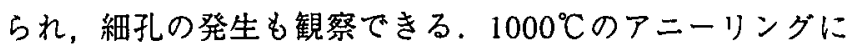
よってTMTの金属成分である $\mathrm{Zn}$ が蒸発し，そのため細孔が 発生したものと考えられ、これが $\mathrm{M}_{\mathrm{s}}$ の減少を引き起こしたも のと予想される. 


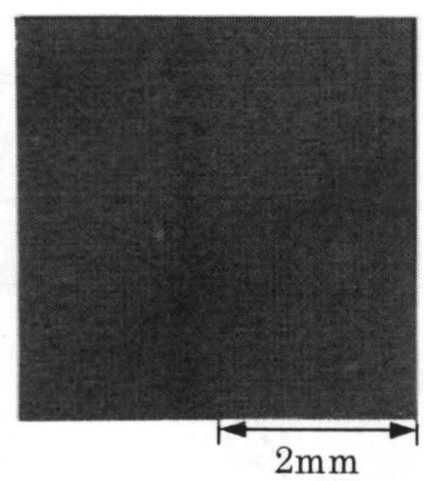

(a) Surface of the TMT that was annealed at $970^{\circ} \mathrm{C}$ for 8 hours.

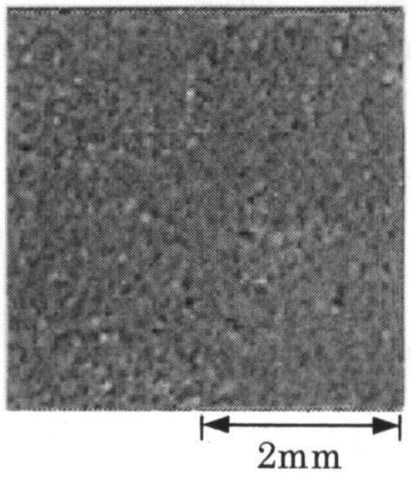

(b) Surface of the TMT that was annealed at $1000^{\circ} \mathrm{C}$ for 8 hours.

Fig.8 Surfaces of TMT.

Fig.9にアニーリング時間によるTMTの飽和磁化 $\mathrm{M}_{\mathrm{s}}$ の変化

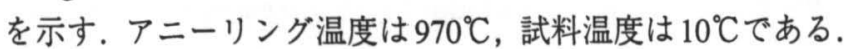
同図より, TMT の飽和磁化は 1 時間のアニーリング処理で大 きな増加がみられ, $108 \mathrm{emu} / \mathrm{cm}^{3}$ を示す. 以後漸次増加傾向が 見られ 8 時間のアニーリングで最大值 $165 \mathrm{emu} / \mathrm{cm}^{3}$ をるが, それ以上のアニーリングで飽和磁化は隇少する。これはア ニーリングによりSTF内の金属元素のスピネル化が時間の経 過とともに促進されることを示している。しかし，一定時間 以上，アニーリングを行うとスピネル成分が減少して磁化が 低下する。

Fig.10に試料温度を変化させたときのTMTの磁化ループを 示す. TMT は $970^{\circ} \mathrm{C} て ゙ 8$ 時間熱処理を施したものである. 同 図より試料温度が $10^{\circ} \mathrm{C}$ のき, 飽和磁化は $165 \mathrm{emu} / \mathrm{cm}^{3}$ を示す が, 温度の上昇に伴い減少し $30^{\circ} \mathrm{C} て ゙ ~ 80 \mathrm{emu} / \mathrm{cm}^{3}, 50^{\circ} \mathrm{C}$ で $15 \mathrm{emu} / \mathrm{cm}^{3}$ まで低下し, 磁化がほほ消失するため, 顕著な温度 依存性を有することがわかる。

Fig.11に TMC と TMT の飽和磁化 $\mathrm{M}_{\mathrm{s}}$ の温度依存性を示す. TMT は $970^{\circ} \mathrm{C} て ゙ 8$ 時間アニーリングを施したものである。バ ルクである TMC の飽和磁化は試料温度が $10^{\circ} \mathrm{C}$ のきには $170 \mathrm{emu} / \mathrm{cm}^{3}$ を示し, $30^{\circ} \mathrm{C}$ で $110 \mathrm{emu} / \mathrm{cm}^{3}, 50^{\circ} \mathrm{C}$ で $16 \mathrm{emu} / \mathrm{cm}^{3}$ と 温度が上昇するにつれ減少し, $50^{\circ} \mathrm{C}$ のきの飽和磁化は $10^{\circ} \mathrm{C}$

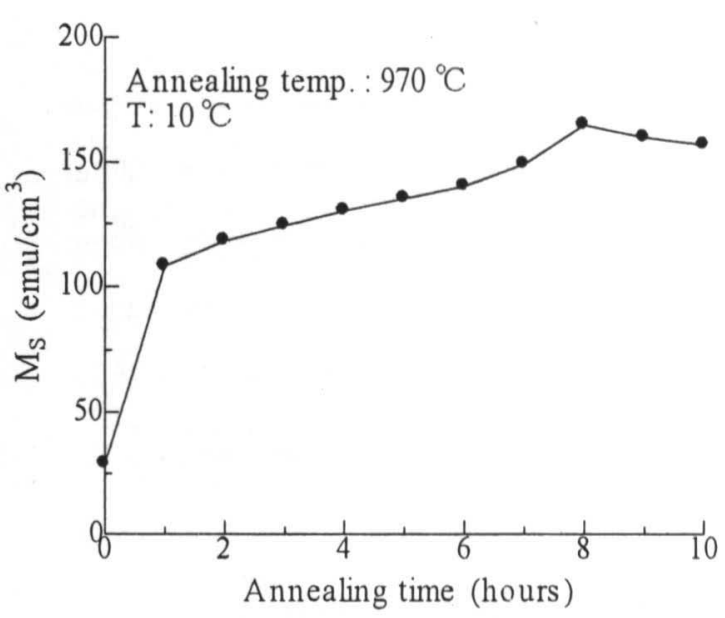

Fig.9 Saturation magnetization $\mathrm{M}_{\mathrm{S}}$ vs. annealing time.

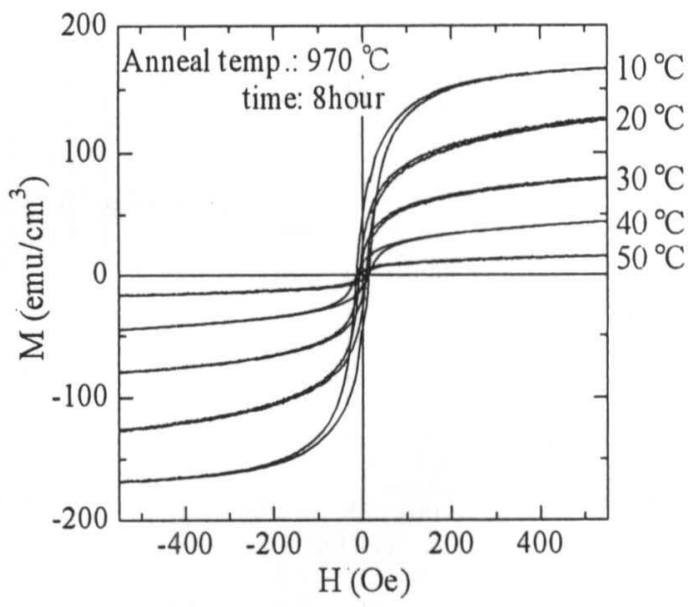

Fig.10 Magnetization loop of TMT with temperature change.

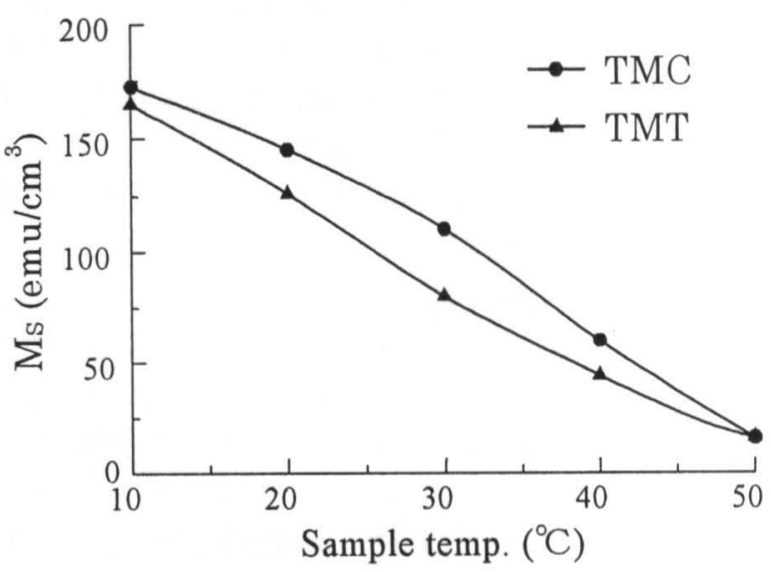

Fig.11 Temperature dependence on saturation magnetization $\mathrm{M}_{S}$ of TMC and TMT

のときの $9.4 \%$ となる. TMT の試料温度が $50^{\circ} \mathrm{C}$ のときの飽和

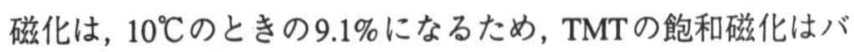
ルクに匹敵する温度依存性を有しているといえる。 
4 TMT を用いた光センサシステムの構成

TMT の応用として光センサシステムについて検討を行っ た. Fig.12はTMTを用いた光センサシステムの構成を示す. $\mathrm{TMT}$ (基板 $\mathrm{S}$ 上に作製)に $\mathrm{MR}$ 素子 MR 固着し，その下部に 永久磁石 $M G$ を接着した構造となっている. 光 L が照射され ると TMTの素子温度が上昇し，それにより TMTの磁気特性 が変化して，MGのバイアス磁束が変動する．MRがこれを検 知し次段の信号增幅回路ICで增幅して出力 $\mathrm{V}_{0}$ を得る，なお， センサ部には MR 素子の感知幅を越えることを防ぐため，受 光面 $\mathrm{S}_{0}$ ( 直径 $3 \mathrm{~mm}$ の円面積 $7.06 \mathrm{~mm}^{2}$ ) なるカバーを施した.

Fig.13はタングステンランプによる白色光を照射した場合 のセンサ出力の過渡応答特性である。測定は周囲温度が $20^{\circ} \mathrm{C}$ の下で行った．ステップ状の光の照射に対して出力電圧は急 激に立ち上がった後，ややゆっくりとした減衰特性を持っ応

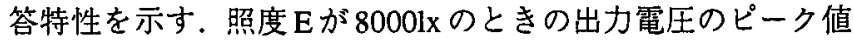
は45mVであった，20001xの照度ではピーク值は $12 \mathrm{mV}, 3001 \mathrm{x}$ の照度では $3 \mathrm{mV}$ へ低下する，すなわち，照射光の強度が高 いまど出力電圧のピーク值が大きくなる傾向を示す，また，

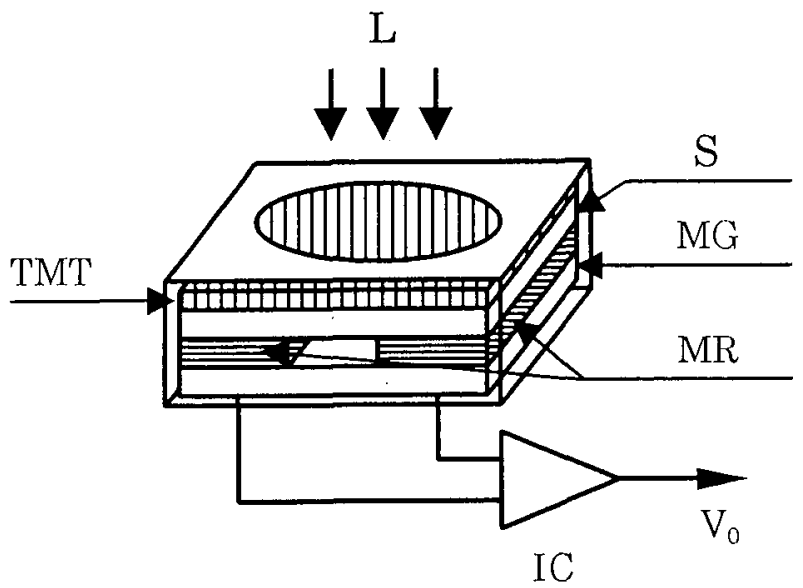

Fig.12 Magnetic signal conversion method using TMT. 80001xの照度の光を照射した場合, 光エネルギーによる TMT の温度上昇は約 $0.5^{\circ} \mathrm{C}$ であり, 出力電圧は入射から約 9 秒後に ピーク值をとり，24秒後に消失する。

Fig.14は照度と出力電圧のピーク值との関係を示すが，同 図より，而者の間にほほ直線的な関係がみられる．周囲温度 が $20^{\circ} \mathrm{C}$ の場合, $3001 \mathrm{x}$ から $8000 \mathrm{x}$ の照度に対し $\mathrm{V}_{0}$ は $3 \mathrm{mV}$ から $45 \mathrm{mV}$ へと増加しており，周囲温度が $25^{\circ} \mathrm{C}$ 場合には $2.5 \mathrm{mV}$ から 40mV まで変化する．また，同一照度では，周囲温度が 低いほどV。が大きくなる傾向が見られる。このように、TMT は低照度から高照度までの光に応答するため, 光センサとし て十分な機能を有しているものと考えられる。

\section{5 結 論}

以上，感温磁性薄膜デバイスの作製と基礎特性，抢よび光 センサシステムの構成について報告した．感温磁性薄膜はバ ルクである感温磁性コアをターゲットとして，スパッタリン グにより金属粒子を堆積させた後，アニーリングによって作 製される。これまで，温度依存性を有する磁性薄膜の作製は 困難であるとされていたが，本方法は，アニーリング工程で， 非晶質であるスパッ夕膜にスピネル構造を持たせることによ り感温磁性薄膜 (膜厚 $1.5 \mu \mathrm{m}$ ) を作製することができた。 アニ ーリングはアルゴンガス中で行われるので，過剩な酸素を遮 断し，粒子の成長に必要な環境を保持することにより大きな 磁化が得られる。感温磁性薄膜の飽和磁化は, 感温磁性コア と同等の大きさをもち，顕著な温度依存性を有している，ま た，ここで報告した感温磁性薄膜デバイスは物理的にも化学 的にも極めて安定な素子であり、従来の光センサでは耐えら れない環境での使用が可能である。感温磁性コアや感温磁性 厚膜は熱容量が大きいので熱ロスのため, 微小な温度の検出 に対応できないが，薄膜は熱容量が極めて小さいため，熱応 答特性が優れており高感度のセンシングが可能である。した がって，感温磁性薄膜はマイクロ磁気デバイスとして焦性磁 気センサ，酵素センサなどへの応用が期待される.

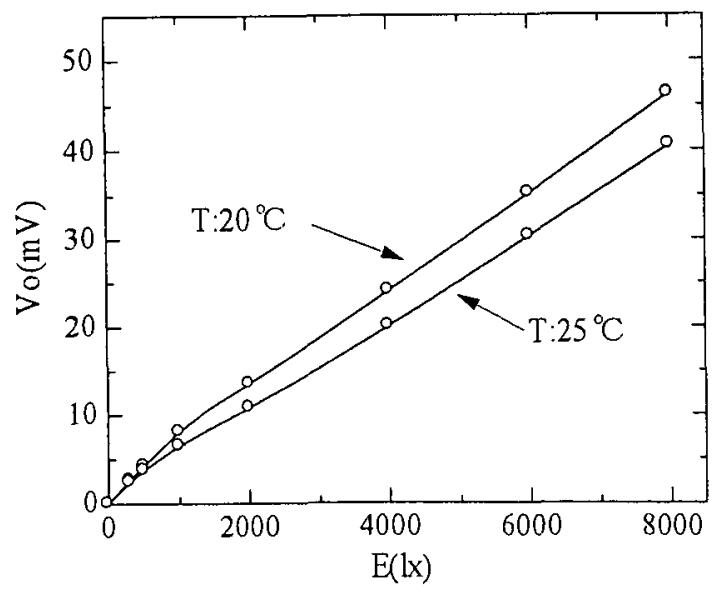

Fig.14 Photo conversion characteristic of TMT. 


\section{文献}

（1）村上孝一, 松木英敏: 感温磁気応用工学, 培風館, (1993).

(2) 関 享士郎, 渋谷崇, 千葉茂樹, 長田 洋, 村上孝一：照明学 会誌, Vol.78, No.10(1994)61.

(3) K.Seki, Y.Nakayama, S.Chiba, Y.Tsunekawa, H.Matsuki and K.Murakami: IEEE Trans. Magn., Vol.29, No.6(1993)3189.
(4) 長田 洋, 安宍善史, 㐘池 孝, 田山典男, 関 享士郎, 菊池新 喜：日本応用磁気学会誌, 20(1996)565-568.

（5）応用物理学会：薄膜作製ハンドブック，共立, (1991).

(6) 小林春洋: スパッ夕薄膜, 日刊工業新聞社, (1993).

(7) 友原健治, 中野正基, 福永博俊: 電気学会研究会資料, MAG-97-186(1997). 